\title{
A Simple Strategy of Control DC-DC Converter as Power Supply on Household Lights
}

\author{
Turahyo* \\ Teknik Elektro, Sekolah Tinggi Teknologi Bontang, Bontang \\ Email: turahyoahyo@gmail.com \\ *Corresponding Author
}

\begin{abstract}
LED lighting is a lamp that is to be provided using AC voltage. The voltage of $220-240$ volts is the working voltage of the LED lighting. Under certain conditions, the driver LED light can also be activated using a DC voltage at a voltage of 120-125 volts DC. In solar cell power plants, storage of electrical energy from solar cells generally uses 2-12 volt batteries. To turn on the LED lighting utilizing the input voltage from the solar cell battery, equipment is needed that can increase the voltage level greater than 120 volts DC. DC-DC converters can be utilized to raise a low voltage level to a higher voltage level. In this paper, the boost converter as a DC-DC converter and the Cockcroft Walton method is used as a power supply for LED lighting in households. After testing, the output voltage from DC to DC is 119.98 volts with a 5-watt lamp loads with a current of $0.0389 \mathrm{~A}$, while the input voltage is 3.7 volts and a current of 1.49 amperes with an efficiency of $84.5 \%$ and is feasible to be implemented.
\end{abstract}

Keywords-DC-DC converter, solar cell, battery, cockcroftwalton, lighting.

\section{INTRODUCTION}

The solar cell power plant generates electrical energy from the conversion of heat energy from sunlight. The hotter the sunlight hitting the solar cell panels. The more electrical energy is produced. This generator is easy to find and easy to install. In addition, the current price of solar cells is relatively cheaper compared to other types of power plants. The process of storing electrical energy generated by solar cells is stored in batteries / batteries using solar charge control (SCC) as a management control [1]. The duration of time used to fully charge a battery depends on the size of the battery capacity [2]. The battery used in the solar cell is a deep cycle dry battery that has a fairly long lifetime, which is around 4-5 years in routine use and is resistant to the surrounding weather. Batteries are used to store electrical energy in solar cells work based on chemical reactions [3-5]. Solar cell batteries generally utilize a voltage of $2-12$ volts DC with a very large current capacity ranging from $7 \mathrm{Ah}$ to $200 \mathrm{Ah}$. The use of solar cells in households is usually used in electrical equipment that absorbs small electrical power such as radios, televisions and lighting.

LED lighting (light emitting diode) is a type of lighting that uses a driver circuit to convert an AC voltage to a DC voltage to a lower voltage level to power the LED circuit. LED lighting is a lamp that has a fairly high efficiency with very low power absorption. To turn on the LED lighting using a battery as the input voltage, a low level DC voltage to high level AC voltage converter circuit is required which is commonly known as an inverter [6]. Household LED lighting work at a voltage of 220-240 volts AC. Under certain conditions, the LED lighting can also be turned on using a DC voltage with a voltage of $120-125$ volts DC. If the LED lamp is powered by a battery with a voltage of 2-12 volts DC, the LED light does not power up. This is because the battery voltage level is not high enough to turn on the LED light as lighting. DC-DC can be utilized to increase low-level DC voltage to high-level DC voltage or vice versa [7] - [9]. A DC-DC converter can use flyback, forward, half bridge and full bridge converter topologies [10] - [11], [12] - [13]. The DC-DC converter in this paper utilizes the boost DC-DC converter method using a flyback converter topology [14] [15]. The DC-DC converter can be implemented using [16], [17] or without a transformer [18] - [19]. The LC oscillator tank is used as a pulse circuit in the DC-DC converter [20]. Besides that, the interleaving method [21] and PWM can be used as a trigger circuit in the DC-DC converter switching [22-24].

Cockcroft-walton is a voltage booster circuit used to increase the $\mathrm{AC}$ voltage level from a low voltage level to a higher AC voltage level by doubling or multiplying the AC input voltage [25-28]. The Cockcroft-Walton method consists of a diode [29] and a capacitor [30] circuits. This method is space-saving, very simple, lightweight and costeffective when compared to the voltage multiplier utilizing a transformer [31]. This paper discusses the design of a boost converters using the Cockcroft-Walton method as a voltage multiplier that can be utilized to turn on household LED lighting.

\section{THE PROPOSED SYSTEM}

A DC-DC converter is a converter that is used to convert DC voltage at a certain level to DC voltage at different levels. In this paper, an input DC voltage with a low voltage level is applicable to produce a higher voltage level. Several types of DC-DC converter topologies that are commonly used include step-down (buck) converters, step-up (boost) converters, step-down / step-up (buck-boost) converters, forward converters, flyback converters, half- bridge, push-pull and full-bridge. In this converter, generally without or using a transformer as insulation. In this paper, a flyback converter topology is used in building a boost converter system as a power supply for lighting lamps. The reason for choosing this topology is based on the form of a flyback converter topology which is simple, cheap and easy in determining the components utilized. The electronic components used in this 
flyback converter consist of a power transistor as an electric switch, a ferrite type transformer as a power supply and voltage level riser, a half-wave surrender on the feedback side and a voltage multiplier using the Cockcroft-Walton method. The load used throughout this paper is a resistive load in the form of a Philips LED lighting that has a working voltage of 200-240 volts AC. Fig. 1 shows a block diagram of the boost converter circuit system as a power supply to the lighting lamp.

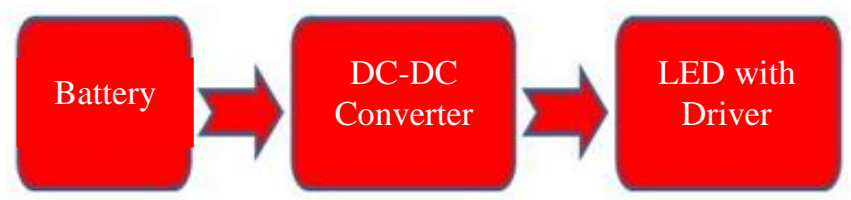

Fig. 1. Block diagram of a DC-DC converter as a power supply to a lighting lamp.

\section{DESIGN DC-DC CONVERTER}

Before implementing the actual circuit, in this paper, simulation of the DC-DC converter circuit is performed first. The flyback converter circuit with a voltage multiplier using Cockcroft-Walton as a DC-DC converter is used in this paper as showed in Fig. 2. The flyback converter topology was chosen in this paper because it is easy, small in size and easy to implement. While the Cockcroft-Walton method is a very simple method to be used as a voltage multiplier. VDC1 as a power supply boost converter which is used to supply DC voltage with low voltage is shown in Fig. 2. The NPN type transistor is used as a power switch in the converter, while the transformer ferrite is used as an oscillator generator to produce a trigger voltage at the base of the transistor. In addition, a ferrite transformer is employed as an AC voltage booster at the output converter. The transformer used has a primary winding with 2 windings on the secondary. The oscillator is produced from the RC filter in this circuit, components $\mathrm{R} 3$ and $\mathrm{C} 1$ as a pulse generator at the base of the power switch transistor. Diode D3 is a diode with high frequency switching characteristics which are used as a halfwave rectifier of the output voltage of the transformer. The combination of diodes D1, D2 and C2, C3 is an AC voltage multiplier using the Cockcroft-Walton method. This paper uses only one stage in the Cockcroft-Walton method. The capacities of capacitors $\mathrm{C} 2$ and $\mathrm{C} 3$ determine the number of output current in the converter. Capacitor $\mathrm{C} 4$ is a DC voltage leveler that has been rectified in a voltage multiplier circuit to get a DC voltage form of a smaller ripple content, while the resistor RL is a replacement circuit for the lighting load. In this paper, LED light with the driver is used as a load on the converter. Table 1 shows some of the parameter specifications used in the boost converter simulation in this paper.

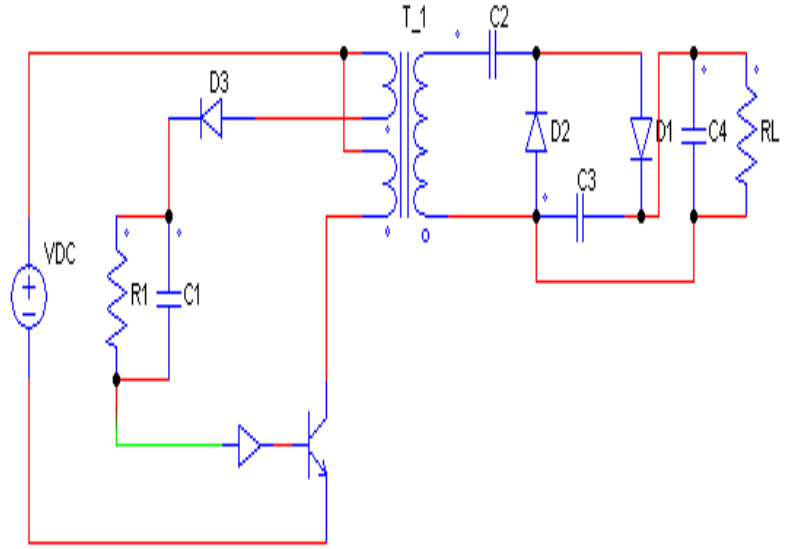

Fig. 2. Design flyback converter and voltage multiplier with CockcroftWalton method.

TABLE I. SimULATION PARAMETER SPECIFICATION

\begin{tabular}{|l|l|l|}
\hline No & \multicolumn{1}{|c|}{ Parameter } & Specification \\
\hline 1 & Power supply voltage & 3.7 volt \\
\hline 2 & Transistor & NPN \\
\hline 3 & R3 & $2 \mathrm{k} 2 \mathrm{Ohm}$ \\
\hline 4 & C1 & $0.47 \mathrm{uF}$ \\
\hline 5 & Primery transformer winding & 17 turns \\
\hline 6 & $\begin{array}{l}\text { Secondary feedback transformer } \\
\text { winding }\end{array}$ & 19 turns \\
\hline 7 & Output secondary transformer winding & 250 turns \\
\hline 8 & C2 dan C3 & $0.01 \mathrm{uF}$ \\
\hline 9 & C4 & $0.2 \mathrm{uF}$ \\
\hline 10 & R Load & $3125 \mathrm{ohm}$ \\
\hline
\end{tabular}

\section{RESUlTS AND DisCUSSION}

Simulation using PSIM software has been made in this paper. In the simulation, parameter specifications are paid as in Table 1. To facilitate the observation at the points of the flyback converter circuit, several probes are used to assess voltage and current. Built on the simulation results, the flyback converter circuit produces a waveform, the amount of output voltage and current as in Figure 3. Fig. 3 shows that the output voltage has a momentary increase of greater than 350 volts. Then decreases to a voltage of close to 0 volts. However, in the next period, the voltage increased to close to 119.98 volts DC. It is lower than 0.005 seconds after the system starts up for the first time. The output voltage experiences a stable state after 0.0045 seconds. This output voltage waveform is a stage 1 output voltage of the voltage multiplier using the cockcroft-walton method.

Fig. 4 shows in the shape of the output voltage after the voltage boost transformer. In this test, the resulting voltage is 107 volts in the form of AC voltage. The voltage experiences a steady state after less than 0.01 seconds. In Fig. 5, a comparison of the shape of the voltage after the stepping transformer and the output voltage multiplier DC-DC converter is shown. 


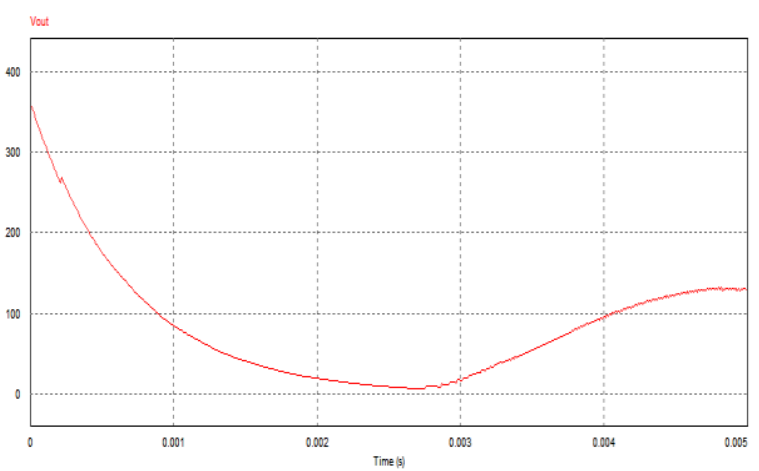

Fig. 3. Form of the flyback converter output voltage.

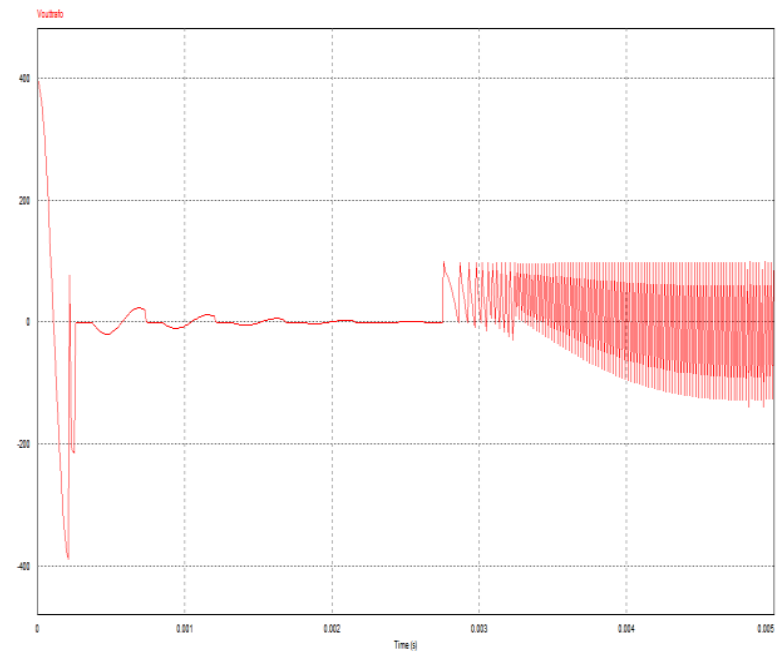

Fig. 4. The shape of the voltage after the step-up transformer.

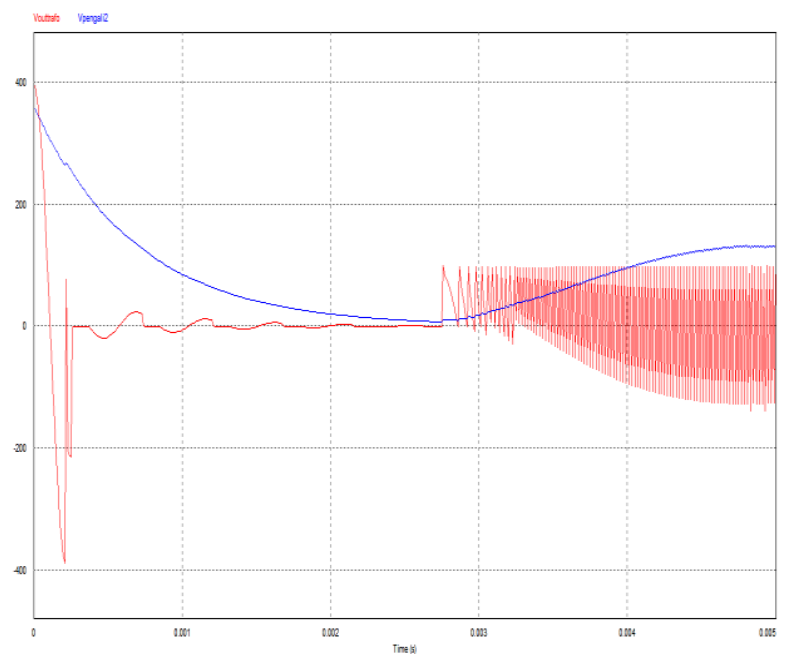

Fig. 5. The shape of the voltage after the voltage stepping transformer and the voltage multiplier output voltage.

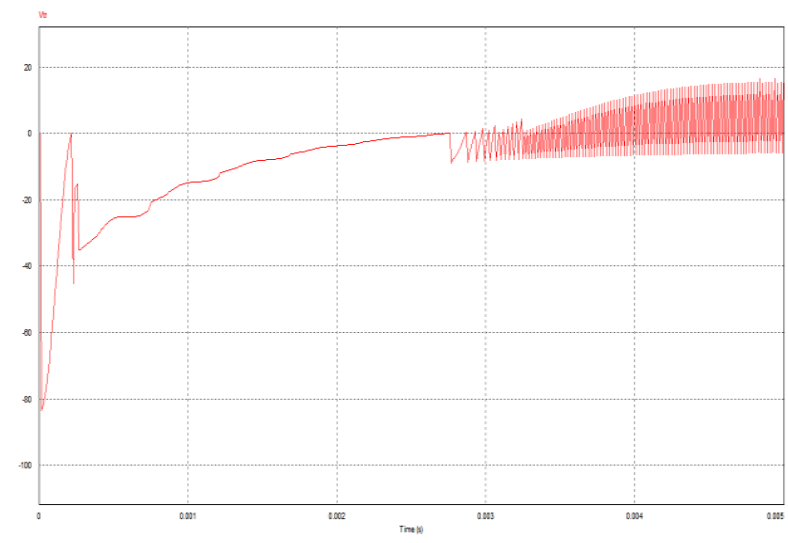

Fig. 6. Form and voltage at the base of the power transistor.

In Fig. 6 shows the form of the input voltage at the base of the power transistor which is utilized to trigger the transistor so that the transistor is in an energized state. The amount of voltage used to produce the energize condition on the base of the power transistor is 13.7 volts. This voltage is generated from the process of rectifying the feedback voltage of the stepping transformer after the system is first powered up. The waveform and voltage magnitude are as showing in Fig. 7. The frequency used as an oscillator at the base of the power transistor so that it is in the energized state is $5 \mathrm{kHz}$.

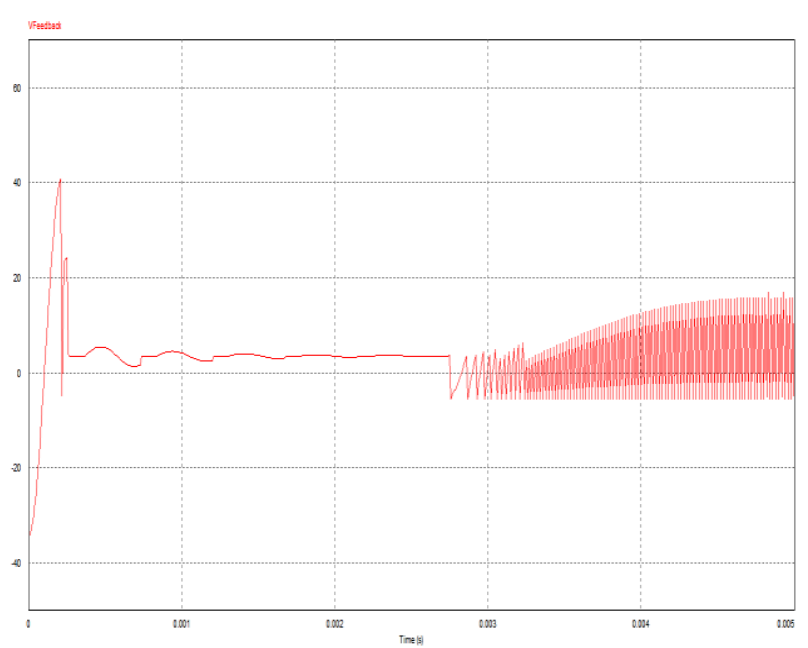

Fig. 7. Form of the feedback voltage of the step-up transformer.

The form of the output current from the boost converter can be shown as in Fig. 8. In this figure, the current required to turn on a 5 watt lighting lamp is 0.0389 A while the DC input current absorbed in this system is 1.49 A. Apart from being the output voltage leveler, the capacitors $\mathrm{C} 3$ and $\mathrm{C} 4$ in this multiplier circuit are also used as limiters for the output current. The form and magnitude of the DC input current in this boost converter are as showed in Fig. 9. 


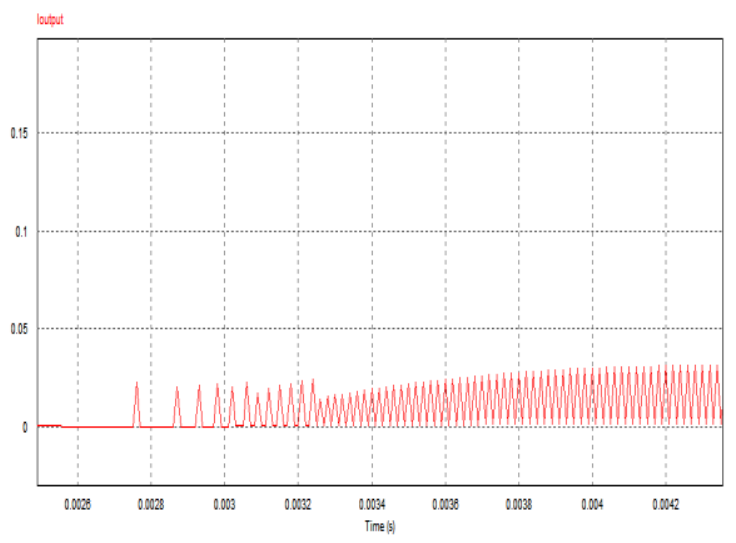

Fig. 8. Forms of output current from DC to DC converter.

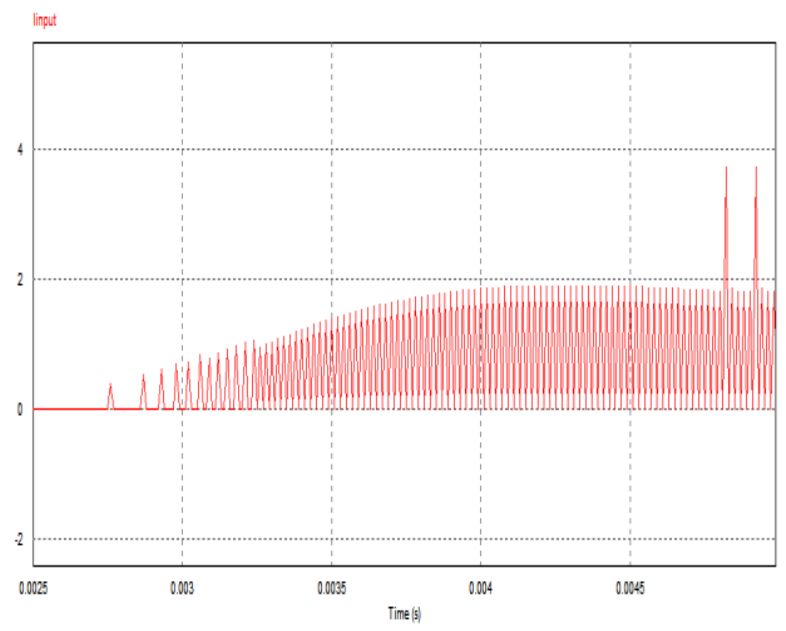

Fig. 9. Form of input current from DC to DC converter.

Based on the simulation results carried out on the boost converter on the input side of the system. The input voltage is 3.7 volts with the absorbed current of $1.49 \mathrm{~A}$. While on the output side of the system, the output voltage is 119.98 volts on the output current on the 5W LED lamp of 0.0389A. The maximum efficiency of the boost converter in this paper reaches $84.5 \%$. These results are obtained from the comparison formula for the input power of the boost converter compared to the output power of the boost converter as in equation 1 . The efficiency of the boost converter is shown in table II.

$$
\eta=\frac{\text { Pout }}{\text { Pin }}=\frac{\text { Vout } x \text { Iout }}{\operatorname{Vin} \times \operatorname{Iin}} \times 100 \%
$$

TABLE II. EFFICIENCY BOOST CONVERTER.

\begin{tabular}{|c|c|c|c|c|c|c|c|c|}
\hline \multirow[b]{2}{*}{ No } & \multicolumn{8}{|c|}{ Parameter } \\
\hline & $\begin{array}{l}\text { Load } \\
\text { (W) }\end{array}$ & $\begin{array}{l}\text { Vin } \\
\text { (V) }\end{array}$ & $\begin{array}{l}\text { Iin } \\
\text { (A) }\end{array}$ & $\begin{array}{l}\text { Vout } \\
\text { (V) }\end{array}$ & $\begin{array}{l}\text { Iout } \\
\text { (V) }\end{array}$ & $\begin{array}{l}\text { Pin } \\
\text { (W) }\end{array}$ & $\begin{array}{l}\text { Pout } \\
\text { (W) }\end{array}$ & $\eta(\%)$ \\
\hline 1 & 5 & 3.7 & 1.46 & 119.98 & 0.0389 & 5.513 & 4.66 & 0.845 \\
\hline
\end{tabular}

\section{CONCLUSIONS}

A Simple control strategy DC-DC converter using low voltage and voltage multiplier with Cockcoft-Walton method was designed and analyzed. The proposed converter was successfully demonstrated to boost $3.7 \mathrm{~V}$ to $119.98 \mathrm{~V}$ with lamp load of $5 \mathrm{~W}$. The current Absorbed in the DC-DC converter circuit is $1.49 \mathrm{~A}$ with an output current of $0.0389 \mathrm{~A}$. The resulting efficiency from the DC-DC converter circuit is $84.5 \%$.

\section{REFERENCES}

[1] Ario F. Nurman, "Product development and deployment of power converter for $15 \mathrm{~kW}$ solar off-grid power plant in PT. Len industri," The seconds IEEE Converence on Power Engineering and Renewable Energ (ICPERE), pp. 301-306, 2014.

[2] Mirandha R.H, "Rancang bangun charger baterai untuk kebutuhan UMKM,' Jurnal Teknologi Terpadu, vol.4, no. 02, pp. 130-136, 2017.

[3] Amirudin E, "Pengaruh penambahan vitamin baterai VITTA-Q terhadap load test pada lead acid battery tipe liquid vented $12 \mathrm{~V}$ Ah. Jurnal Pendidikan Teknik Kejuruan,” vol 4, no2, pp. 1-6, 2015.

[4] Rezaei B, “ Influence of acidic ionic liquids As An electrolite additive on the electrochemical and corrosion behaviors of lead-acid battery. Journal Solid State Eletrochem,” vol. 15, pp. 421-430, 2011.

[5] Yamaguchi Y, "In Situ analsis of electrochemical reactions at A lead surface in sulfuric acid," Journal Power Source," vol. 85, pp. 22-28, 2013.

[6] Turahyo, T, " Desain Inverter Satu Fase menggunakan Metode DDS untuk Mengurangi Konsumsi Daya Lampu Papan Reklame," Emitor: Jurnal Teknik Elektro,” vol.20, no.1, pp. 52-55, 2019.

[7] Tyagi Preti, Sunder P.S and Kotak V.C, "Design high gain DC-DC boost converter with coupling inductor and simulation in Psim," International Journal of Research in Engineering and Technology (IJRET), vol.03, no.04, pp.156-163, 2014.

[8] Febriyandi Imam, Wijaya F.D, and Firmasyah Eka, "DC-DC Converter as power supply of battery charger $100 \mathrm{~V} 300 \mathrm{~W}$ using $25 \mathrm{kHz}$ switching frekuency," IEEE international Converence on Electrical Engineering and Computer Science. 2014.

[9] M. A. Razzak, S. Chakraborty and Z Tasneem," Design of a Multistage 0.1/12 kV DC-DC Matrix Converter using Cockcroft-Walton Voltage MultiplierTopology" IEEE international WIE conference on electrical and computer engineering, pp. 309-312, 2015.

[10] M. Prathibha R and H. Sridhar S, "High Step-up High Frequency Push Pull DC-DC Converter Using MPPT With DC Motor Load," 2017 International Conference on Computation of Power, Energy, Information and Communication (ICCPEIC), pp. 677-680, 2017.

[11] Nirmal and Kumar Piyush Jain. "Interleaved DC to DC Buck Converter for Low Power Application," Conference: 2015 International Conference on Energy, Power and Environment: Towards Sustainable Growth (ICEPE). pp.1-5, 2015.

[12] Ikeda Satoshi and Kurokawa Fujio. "Boost Full Bridge DC-DC Converter Ensuring Safe Installation of PV Energy in Data Center Power Management Systems," Conference: 2017 IEEE International Telecommunications Energy Conference (INTELEC). pp. 530-534, 2017.

[13] Kishore, G, Manoharan, Premkumar, Tripathi, Ramesh, Nalamati, and Chandra Sekhar,"A Novel Single Switch High Gain DC-DC Converter Topology for Renewable Energy Systems," Energy Engineering: Journal of the Association of Energy Engineers. pp.118. 1-11, 2020.

[14] N. Bernhard AGL, F. Albert Rafetseder, P. Josef Fohringer, and A.Felix H," DC-to-DC Converter Simulation Applied to a Modified Boost Converter," EUROCON 2007 The International Conference on Computer as a Tool, Warsaw, September 9-12, pp. 1594-1600, 2007.

[15] Dasari Kiran Ravi and Immanuel D,"Comprehensive Review of Single Switch DC-DC Converters for voltage lift in RES application," 2018 International Conference on Power, Energy, Control and Transmission Systems (ICPECTS), pp.281-288, 2018. 
[16] Lin Weixing,"DC-DC Autotransformer With Bidirectional DC Fault Isolating Capability," IEEE TRANSACTIONS ON POWER ELECTRONICS, vol. 31, no. 8, pp. 5400-5410, 2016.

[17] Lin Ray-Lee and Pan Chi-Rung,"Family of Single-Inductor MultiOutput DC-DC Converters," Conference: Power Electronics and Drive Systems, 2009. PEDS 2009. International Conference on.pp. 12161221, 2009.

[18] Hu Xuefeng and Zhang Jiayan,"A novel dual-output DC-DC converter topology Without Transformer," 2010 International Conference on Electrical and Control Engineering, pp. 187-189, 2010.

[19] Pandey Brajesh," A Novel Approach for On-chip Step Down DC-toDC Converter with DC Voltage Control," 2013 7th Asia Modelling Symposium, pp.311-313,2013.

[20] Lai Wen-Cheng and Jang Sheng-Lyang,"Fully-Integrated CMOS DCDC Boost Converter," 2019 The Asia Power and Energy Engineering Conference, pp84-88, 2019.

[21] Ravi Deepak and Sudha Letha Shimi and Samuel Paulson,"An Overview of Various DC-DC Converter Techniques used for Fuel Cell based Applications," Conference: 2018 International Conference on Power Energy, Environment and Intelligent Control (PEEIC), pp.1621,2018

[22] Takimoto Takashi and Kuchii Shigeru,"Control of DC-DC Converters with Pulse Width Modulation Inputs," ICROS-SICE International Joint Conference 2009, Fukuoka International Congress Center, Japan, August 18-21, 2009.

[23] Fan Liping," Exponential Approaching Sliding Mode Control of PWM DC/DC Converters," 2010 International Conference on Electrical and Control Engineering, pp.5223-5226, 2010.
[24] L. Mamdouh Alghaythi,"'Design of a High Step-up DC-DC Power Converter with Voltage Multiplier Cells and Reduced Losses on Semiconductors for Photovoltaic Systems," International Research Journal of Engineering and Technology (IRJET), vol. 05, no. 11, pp. 797-801, 2018.

[25] Sari Nofita Ginting and Syakur Abdul,"Perancangan Pembangkit Tegangan Tinggi DC dengan Metode Cockcroft-Walton Tipe Fullwave," TRANSIENT, vol. 7, no. 2, pp. 443-448, 2018.

[26] Dash Sambit, "A novel Method of Starting of a Fluorescent Lamp with Cockcroft Walton Voltage Multiplier," IEEE International Conference on Technologies for Smart-City Energy Security and Power (ICSESP2018), March 28-30, 2018.

[27] Ding Xinping, Zhao Delin, and Liu Yun, "Improved Cockcroft-Walton Single Stage High Voltage Gain Inverter," 2019 22nd International Conference on Electrical Machines and Systems (ICEMS), 2019.

[28] Lamantia Antonio and Radrizzani Luca," Small-Signal Model of the Cockcroft-Walton Voltage Multiplier," IEEE TransactionS ON Power Electronics,vol. 9, no. 1, pp. 18-25, 1994.

[29] Fairchild Semiconductor, UF4001-UF4007 datasheet 1.0 ampere glass passivated high efficiency rectifier, 2007.

[30] C. Ioannis. Kobougias and C Emmanuel Tatakis, "Optimal Design of a Half-Wave Cockcroft-Walton Voltage Multiplier With Minimum Total Capacitance," IEEE Transactions on Power Electronics,vol. 25, no. 9, pp. 2460-2468, 2010.

[31] Rajaei Amirhossein, "A Dual Inductor High Step-Up DC/DC Converter Based on the Cockcroft-Walton Multiplier," IEEE Transactions On Power Electronics, vol. 33, no. 11, pp. 9699-9709, 2018. 